\title{
Migration of Croatian physicians in the global context
}

\section{Migracija hrvatskih liječnika u globalnom kontekstu}

\author{
Ema Gruber ${ }^{1 *}$, Iris Sarajlic Vukovic ${ }^{2}$, Martina Musovic ${ }^{3}$, Davor Moravek4, Branka Starcevic ${ }^{5}$, \\ Sanja Martic Biocina ${ }^{6}$, Rajna Knez ${ }^{7}$
}

${ }^{1}$ Forensic Psychiatry Department, Mental Health Centre Sct. Hans, Roskilde, Denmark

${ }^{2}$ Department of Affective Psychiatry, Sahlgrenska University Hospital, Göteborg, Sweden

${ }^{3}$ Community Treatment Team, Palmers Community Hospital, Northumberland, Tyne and Wear NHS Foundation Trust, Wear St, Jarrow, United Kingdom

${ }^{4}$ GGZ Westelijk Noord-Brabant, FACT Roosendaal, AJ Bergen op Zoom, Netherlands

${ }^{5}$ Psychiatric hospital in Bod $\varnothing$, Acute psychiatric ward, Bod $\varnothing$, Norway

${ }^{6}$ Head of the Department of Social Psychiatry, University Psychiatric Hospital Vrapce, Zagreb, Croatia

${ }^{7}$ Skaraborgs hospital, Skövde, Sweden

\author{
*Corresponding author: \\ Ema Gruber, psychiatrist, \\ Forensic Unit R4, Department R, \\ Mental Health Centre Sct. Hans, \\ Boserupvej 2, 4000 Roskilde, Denmark, \\ e-mail: emagruber2000@yahoo.com
}

Abstract. As the global health care workforce faces a shortage, several EU nations focus on employing foreign-trained physicians. So much so, that in some countries of the $\mathrm{EU}$, the percentage of foreign-trained physicians has reached $30 \%$ and the percentage of foreigntrained psychiatrists has risen to $40 \%$. After Croatia entered the EU, together with a significant number of other Croatian citizens, a great proportion of Croatian physicians emigrated. Currently, Croatia is among the three EU countries from which the most physicians emigrate. There are both economic and non-economic factors that are influence individuals' choice to emigrate. Benefits of emigration for Croatian physicians are high satisfaction with life standard, income, professional development, and better work conditions. However, there are also clear psychological costs involved, which hinder both the emigrants and their families, and make building of a social network and integration into society difficult. These are: moving away from family members, friends and a familiar environment, mastering another language, finding work opportunities for partners, adjusting to life in another country under discrimination by colleagues, patients and the general public. Countries of immigration face challenges with foreign-trained physicians because of their native linguistic and cultural background. Language proficiency training and national familiarization programs can improve integration of immigrant physicians and their families. In recognition that national skill shortages can cause disbalance on a global level, the WHO calls on high-income countries to strive for self-sufficiency, through educating, retaining, and sustaining enough physicians to staff their own health care systems.

Key words: integration; migration; physicians; psychiatrists

Sažetak. Zbog nedostatka zdravstvene radne snage na globalnom nivou, velik broj zemalja EU-a usredotočen je na regrutiranje i zapošljavanje stranih zdravstvenih stručnjaka. Postotak liječnika stranaca u nekim zemljama EU-a penje se do $30 \%$, a postotak stranih psihijatara čak do $40 \%$. Nakon ulaska Hrvatske u EU znatan broj liječnika, zajedno s velikim brojem građana, odlučio je emigrirati iz Hrvatske. Trenutno je Hrvatska jedna od tri zemlje EU-a s najvećim brojem zdravstvenog osoblja koje se iseljava. Čimbenici važni za odluku o iseljeništvu su i ekonomski i neekonomski. Prednosti života u iseljeništvu za liječnika iseljenika su viši životni standard, viši prihodi, profesionalni razvoj, bolji radni uvjeti, a nedostaci za liječnika i njegova partnera i djecu su odlazak od šire obitelji, prijatelja i poznatog okruženja, savladavanje novog jezika i prilagođavanje životu u drugoj zemlji te percepcija diskriminacije od strane kolega, pacijenata i šire javnosti u zemlji iseljeništva, što otežava izgradnju socijalne mreže i integraciju u društvo. Zemlje iseljeništva stoje pred izazovom integracije stranih liječnika koji imaju različitu jezičnu/ kulturnu pozadinu. Jezična obuka i programi uvođenja u sustav mogu olakšati integraciju liječnika iseljenika i njihovih obitelji. Uočavajući činjenicu da nacionalni nedostatak pružanja zdravstvenih usluga može uzrokovati daljnju neravnotežu na globalnoj razini, Svjetska zdravstvena organizacija poziva zemlje EU-a koje regrutiraju strane liječnike da umjesto regrutiranja potiču samodostatnost u pružanju zdravstvene skrbi, odnosno da educiraju, zadržavaju i održavaju dovoljan broj vlastitih liječnika za pružanje zadovoljavajuće zdravstvene zaštite.

Ključne riječi: integracija; migracija; liječnici; psihijatri 


\section{INTRODUCTION}

As the global healthcare workforce is facing a shortage ${ }^{1}$, several countries' health care systems focus on employing foreign-trained health professionals. Already in 2012, the European Commission estimated that Europe could be short of 230,000 doctors by 2020 . This would mean that $13.5 \%$ of Europe's health needs would not be taken care of. Recently, more attention has been redirected in investing in education and training of native physicians, in accordance with the guidelines from the $\mathrm{WHO}^{2}$.

After Croatia entered the EU in 2013, a significant number of citizens, including a great proportion of doctors, both psychiatrists and doctors of other specialties, decided to emigrate from Croatia ${ }^{3}$. Both economic (measured by different GDP and labour market indicators) and non-economic factors (capturing the EU accession, the level of corruption in the economy ${ }^{4}$, and demographic characteristics of the origin country population) are relevant for emigration decisions ${ }^{4}$. Although emigration currents in Croatia, following the accession, are sizeable, they do not represent an isolated case. Bulgaria and Romania also experienced relatively similar population outflows after accession in $2007^{5}$.

The intention of this review is to call attention to the newest comprehensions about migration of Croatian physicians and to describe and discuss the process of medical migration and integration of physicians in immigration countries.

\section{MEDICAL MIGRATION}

Health professional migration represents a "brain drain" of highly skilled and qualified individuals $s^{6,7}$. In their recognition on the fact that national skill shortages can cause further imbalance at a global level, the WHO Global Code on International Recruitment of Health Personnel calls on high-income countries to strive for self-sufficiency. The core stone of WHO's Global Code of Practice on the International Recruitment of Health Personnel is that countries should achieve health workforce self-sufficiency ${ }^{8}$, which requires not only the generation of efficient numbers of health care professionals, but also the implementation of policies and initiatives to enhance their retention ${ }^{9}$. In response to this problem, the Global Strategy on Human Resources for Health calls for a decreased reliance on foreign-trained physicians ${ }^{2}$.

In reality, in some European countries, austerity related cuts to health spending since 2008/2009, and long standing issues such as the need for clearer training and career progression pathways, as well as need to comply with the European Working Time Directive, lead to the need for consultant delivered health service ${ }^{9}$.

There are both economic and non-economic factors that are influence individuals' choice to emigrate. Benefits of emigration for Croatian physicians are high satisfaction with life standard, future security and life achievements. Major challenges are communication (language), integration into the community, and loss of friends and family connections.

On the other side, in some low- and middle-income countries, migration is regarded as an essential component of a successful medical career. Amongst else, training and practicing medicine outside of the native country is considered superior and is a mark of achievement ${ }^{10}$.

At a broader level, the free movement of physicians has advantages - providing an opportunity for physicians to obtain new skills, to enhance their careers and/or their earning potential, and to provide a better future for themselves and their families. Through facilitating sharing of skills and knowledge, medical migration can advance medical research and improve practice. At a national level, medical migration can reduce physician unemployment and/or underemployment, as well as generate a valuable remittance flow to the source country ${ }^{11}$.

The Global strategy for Human Resources for Health acknowledges the potential benefits of international migration, while it also highlights the importance of retention to the delivery of healthcare. For a health care system to function, it must train and retain enough physicians to deliver care ${ }^{11}$.

The literature on health worker migration is dominated by push/pull analyses ${ }^{12,13}$. This kind of analy- 
sis is important but cannot fully explain the complexities of migrant decision making. It is known that political, economic and cultural factors are significant, and that global connectivity enables professionals to continually compare the working conditions and quality of life available in key destination countries. This global connectivity mainly informs migration decision making ${ }^{14}$. Conell $(2014)^{15}$ has highlighted the potential impact of migration cultures, national and professional, on health worker migration, in which professional culture of medical migration encourages rather than discourage physicians to emigrate, by considering it acceptable and necessary, rather than problematic. Many successful physicians have and enjoy boundlessly international and global careers, akin to those of professional football players and other elite groups of highly skilled professionals ${ }^{16,17}$.

Almost all countries continuously struggle with out-of-date and incomplete datasets on migration. While the need for data on the numbers and destination of health professionals who emigrated is greater in the source country, it is easier to collect data in the destination country. Measuring migration intentions has been found to be a predictor of subsequent migration and is a good proxy considering the limitations of generating longitudinal data to empirically test the link between intentions and actual behaviour. For example, the longer that health professionals remain abroad, the less likely they are to return to their home countries ${ }^{18}$.

Emigration of physicians also constitutes that those who best understand the shortcomings of the healthcare system and who might be well placed to challenge and improve that system, emigrate. In this way, the health care system is deprived of potential leaders who might otherwise demand, initiate, and deliver reform ${ }^{11}$.

In the last few decades, in many traditional destination counties, academic and policy attention is turned to the topic of professional integration of foreign-educated health professionals in order to help them in the process of re-socialisation and integration $^{19}$.

\section{STAGES OF MIGRATION}

According to research ${ }^{20}$, the stages of migration have been identified as: pre-migration (assess- ment, reasons, sudden or planned, preparation), migration (age on arrival, reversibility) and postmigration (aspiration, achievement, culture shock, cultural bereavement, culture conflict, acculturation). Duration of post-migration adjustment may last a long time and may even stretch across generations ${ }^{20}$.

Cultural bereavement is due to loss of social structures, cultural values, and cultural identity, and is highlighted by an almost unnatural attachment to the past ${ }^{21}$. This may also be considered idealization of the past and seeing the culture left behind as perfect or ideal.

Individuals' personalities will influence their response to migration ${ }^{21}$. Some may experience "odd" feelings of guilt for abandoning their loved ones and/or family. Another response is a "culture shock", experienced by some migrants after being faced with the new culture ${ }^{22}$. It results in anxiety and feelings of helplessness and incapable. It may feel as though the new culture is not only remarkably different, but also unwelcoming and alien. Similarly, the notion of culture conflict, which relates to a degree of conflict between two members of the same culture, but often across generations ${ }^{23}$, also presents often.

Acculturation (i.e. psychological or behavioural change resulting from migration) deals with the cultural and psychological change that an individual experience following contact with cultural groups and/or individual members ${ }^{24}$.

Assimilation is the process of adjustment, during which exposure to two cultures (one to which the individual belongs and the other to which they have migrated) lead to the individual acquiring the attitudes of the new culture, gaining historical perspective, and sharing experiences. This may lead to the individual being absorbed into the majority culture and to them losing subtle nuances of their native culture ${ }^{21}$.

The integration of immigrant health professionals is connected with multiple barriers: good knowledge of the host country's official language ${ }^{25}$ (i.e. technical workplace-related language ${ }^{26}$ ), different standards for working in health professions ${ }^{27}$, lack of supporting structures ${ }^{26}$, and unfamiliarity with the host country's health care system, procedures, and standards ${ }^{28}$. This may lead to de- 
skilling ${ }^{29}$, loss of self-confidence ${ }^{30}$, and high levels of frustration ${ }^{31}$. The experience of racial discrimination $^{30}$ and structural inequality ${ }^{32}$ in the host country's environment also hinder the integration process.

In addition to having to adapt to a new socio-cultural environment, foreign-qualified health professionals may face professional challenges that include different legal and ethical contexts, and divergent cultural and communication styles even when migrant health workers are fluent in the receiving country's language. Different technologies, professional roles, as well as patient characteristics or patient load can make professional life a challenge, especially if professional peer groups of similar backgrounds are missing ${ }^{33}$. In many cases, adaptation to the workplace will be required, with the migrant required to adapt to a new situation and different meanings and connotations of concepts, such as the relationship with and autonomy of the patient. At the same time, "domestic" staff may be torn by the need to support the new worker and to assist him/her in adjusting to the new situation around the clock, as this may contribute to their workload - the very problem which triggered hiring from abroad in the first place ${ }^{34}$. Moreover, the arrangements made for the entry of new staff may induce jealousy ${ }^{34}$, which in turn may be perceived by the migrant as mistrust and discrimination. Such perceptions and experiences can add to social isolation due to a lack of social networks and loneliness.

Migrating health workers may also end up working in circumstances that are not what they aimed for, while deskilling, combined with discrimination (or perceived discrimination) ${ }^{34}$, is a frustrating experience.

Deskilling happens in most migratory processes, where people must "step down" from their previously acquired qualifications and status to make a living in the receiving country, especially when recognition of higher education and qualifications is involved and is irrespective of the original qualification achieved and/or experience gained $^{35}$. Migrating health workers end up working in circumstances that are not what they aimed for ${ }^{35}$. Previous studies showed that multi- ple forms of workplace mistreatment (e.g., racism, ageism, and sexism) are associated with poor physical health and worsening mental health ${ }^{36}$.

\section{EMIGRATION FROM CROATIA}

Croatia has traditionally been predominantly an area of emigration, while emigration promoted and/or caused by economic and political factors has assumed permanent features throughout all historical periods ${ }^{37}$. Conventional destinations such as Germany, Austria, Switzerland, and Italy, which also attracted Croatian emigrants during the Gastarbeiter era (1960s-1980s), are still the most prevalent destinations for Croatian emigrants $^{37}$.

Croatian citizens emigrated abroad, by country of next residence, $2018^{3}$ are shown in Figure 1.

According to data from the Croatian Bureau of Statistics, 172812 Croatian citizens emigrated in the period of 2014-2018 ${ }^{3}$. Such developments raised emigration-related issues to the forefront of public debate in Croatia. Drawing on a mixture of anecdotal evidence, ad hoc surveys and social network posts, the media predominantly engaged in painting and propagating a bleak picture of the "Croatian exodus"3. Both economic (measured by different GDP and labour market indicators) and noneconomic factors (capturing the EU accession, the level of corruption in the econo$\mathrm{my}^{4}$, and demographic characteristics of the origin country population) are relevant for emigration decisions ${ }^{4}$. According to Pilar's Barometer of Croatian Society, $77 \%$ of Croatian people assess the current situation (perception of their social status in Croatia), bad and very bad $^{38}$. Previous research conducted on 1200 Croatian individuals, who emigrated to Germany between 2013 and 2017, has shown that a "new wave" of migrants are leaving the Republic of Croatia due to socio-political and economic causes, with the foregoing carrying more significance (especially perception of corruption) ${ }^{39}$. The emigrants of the "new wave" are satisfied with their income, work, and life as a whole after emigration; they do not regret emigration, and most of them do not wish to return ${ }^{39}$. Other research has brought to light that the current emigration 


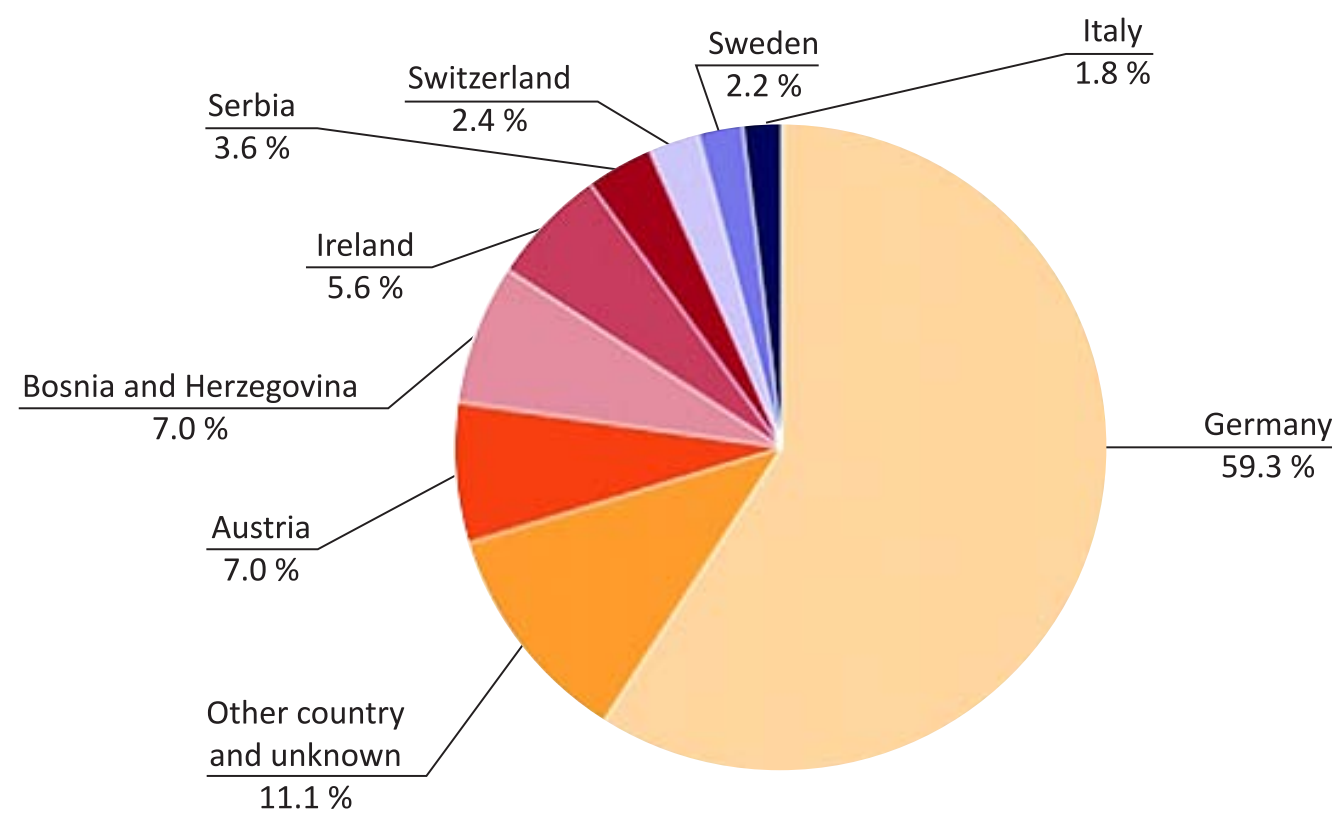

Figure 1. Croatian citizens emigrated abroad, by country of next residence, 2018

8/1/2020, kl. 9.45 was Drzavni zavod za statistiku RH (Croatian Board for Statistics) contacted over the phone (01 4806 138) and the information on copyright notice is obtained: It is free re-use of its data, both for non-commercial and commercial purposes. All statistical data, metadata, content of web pages or other dissemination tools, official publications and other documents published on its website, with the exceptions listed below, can be reused without any payment or written license provided that:

- the source is indicated as Drzavni zavod za statistiku (Croatian Board for Statistics);

- when re-use involves modifications to the data or text, this must be stated clearly to the end user of the information.

wave, in significant proportion, consists of individuals that move with their families ${ }^{40}$. Slightly less than two-thirds of the subjects identified the inability to earn enough funds for a normal life as one of the key causes of emigration. More than half of the subjects emphasized the widespread corruption in society amongst causes of emigration, a third recognized a general feeling of bigotry in society, and a fourth accentuated poor effectivity of social institutions ${ }^{40}$.

A Croatian study from 2014 showed that the percentage of students who wanted to emigrate right after Croatia joined the EU was also high. The study included 260 respondents, out of which $35 \%$ reported readiness for permanent emigration due to expectancy of a greater quality of life, better health care, more professional opportunities, or simply wanting to find a workplace ${ }^{41}$.

It is physicians aged between 27 and 40 years that apply for work abroad ${ }^{42}$. Their main motivators for setting out are better working conditions, more efficient health care systems, better mate- rial conditions and income, as well as a greater chance of professional and medical advancement. During the time since Croatia entered the EU, according to the Croatian Medical Chamber (CMC), in total 1830 physicians asked for a Certificate of Conformity of Education of Medical Physicians through Directive 2005/36 / EC ${ }^{43}$.

A number of recruitment firms provide services that help with connecting healthcare professionals to hospitals in EU countries as well as provide language courses. In this way, Croatian physicians are approached with offers for various positions as staff specialists in EU countries ${ }^{44}$.

According to the data from the CMC, 570 physicians emigrated from Croatia between 2013 and 2016, while 33 of them were psychiatrists ${ }^{42}$, and the most common countries of destination were Sweden, Ireland, Germany, Austria, and the United Kingdom ${ }^{42}$.

A study on Croatian physician emigrants, conducted in September of $2019^{45}$, with a sample of 62 subjects, has shown that Croatian psychia- 
trists have emigrated to Scandinavia in $65 \%$ of the cases, and to West Europe in $30 \%$ of the cases. Other physicians were shown to have emigrated to Middle Europe in $29 \%$ of the cases, to West Europe in $25 \%$ of the cases, and to Scandinavia in $42 \%$ of the cases ${ }^{45}$.

In the media, claims that economic incomes are not the primary cause of unsatisfied physicians can be found. It is reported that they are most bothered by poor working conditions, undemocratic methods, exploitation of interns, crude hierarchies, etc. However, they are surely also lured by economi c resources ${ }^{46}$.

CMC representatives warn that the greatest problem for Croatia is the stagnancy in introducing of young individuals into specialization programs, which are sometimes waited on for as long as 6 months. Furthermore, they alert that the conditions for specialisation are unacceptable and that the agreements negotiated are more often than not "slavery contracts" ${ }^{42,43}$. The problem is, amongst all else, in the legal (de)regulation, which effectively serves as a "push factor" for physicians' emigration, as it causes many judicial proceedings ${ }^{47}$. Through legal deregulation, health care institutions themselves offer varying contracts with different requirements for interns - in some cases up to a million Croatian kunas are required as compensation for breach of contract ${ }^{47}$. Other than that, their position depends upon the will of institution managers, the local community, and the political stance of the ruling party, which decide their destiny as soon as the contract of employment or the mutual rights and obligations agreement is signed ${ }^{47}$. This is in clear contradiction with the European right of free movement of workers, and undeniably motivates emigration of physicians, which is exactly the opposite effect from the intended by the aforementioned measures aim to achieve ${ }^{47}$.

A study conducted in September of 2019, on a sample of 62 Croatian physicians (Croatian emigrant psychiatrists and physicians, and physicians currently working in Croatia), of which the aim was to investigate possible differences in personal wellbeing and work ability between Croatian emigrant psychiatrists and Croatian emigrant physicians of other specialties compared to psy- chiatrists currently working in Croatia, has shown that the satisfaction with standard of life, future security, and life achievements is significantly higher in emigrant psychiatrists than in psychiatrists currently working in Croatia ${ }^{45}$. Satisfaction with integration into the community and with close relationships are significantly higher in emigrant physicians of other specialties than in emigrants psychiatrists ${ }^{45}$. The Work Ability Index score of the 3 groups (emigrant psychiatrists, emigrant physicians of other specialities, and psychi-

As the global health care workforce faces a shortage, several EU nations focus on employing foreign-trained physicians. In some countries of the EU, the percentage of foreign-trained physicians has reached $30 \%$. Countries of immigration face challenges with foreign-trained physicians because of their native linguistic and cultural background.

atrists currently working in Croatia) placed them all in the same category of "good work ability". For all emigrants and their family members, major challenges after emigration were found to be communication (language), integration into the community, and loss of friends and family connections. $70 \%$ of the emigrants tested plan to return to Croatia in the future, but this decision is dependent on better living conditions (income), change in the political situation in Croatia (reduction of corruption), and change in people's mentality ${ }^{45}$.

\section{FOREIGN PHYSICIANS IN OTHER EU COUNTRIES}

There are 2100 foreign physicians employed in Denmark. In some regions of Denmark, $30 \%$ of the physicians are foreign-trained ${ }^{48}$.

During the course of 2014, 2378 physicians in Sweden gained work permit, and $58 \%$ of those were educated outside of Sweden ${ }^{49} .1000$ were educated in Sweden, 1155 were educated in EU/ ESS while 223 were educated in non-European nations ${ }^{49}$. In order to help newcomers to adapt to the Swedish system, the West Gotland County stakeholders decided to offer a special program, called Program Plus ${ }^{50}$. 
In recent years, approximately $16 \%$ of the medical practitioners and $20 \%$ of the specialists in Norway have been international medical graduates with foreign citizenships ${ }^{51}$.

The Netherlands has many psychiatrists compared to other countries, but there is skewed distribution, meaning that they are not always geographically well distributed throughout the country. In total, there were an estimated 800 to 1000 vacancies for psychiatrists in 2017 (this number fluctuates due to opening and closing of places) $)^{52}$.

As of July 2017, over one third (37\%) of doctors on the General Medical Council list of registered medical practitioners in the UK had gained their primary medical qualification outside of the $U^{53}$. Following the vote in favour of Brexit in 2016, the British government has been trying to ensure that European doctors, among others, are not adversely affected and can continue working in the UK, but concerns remain, and foreigners no longer feel welcome ${ }^{53}$.

In 2015, the German Medical Association reported a total of 189622 physicians working in German hospitals ${ }^{54}$. Every sixth physician (tot. 30,595 ) was from abroad - three times the number compared to that recorded in 2000. Most of the immigrant physicians come from other European countries; especially from Romania ${ }^{55}$.

In 2015, $35.7 \%$ of physicians on the Irish register had qualified outside of Ireland ${ }^{56}$. The number of physicians currently working in Ireland is $6,233^{56}$.

Currently, in Austria, $28 \%$ of foreign physicians are from EU countries. The total of 4,410 foreign physicians (excluding dentists) was accredited their foreign certificate in $2011^{57}$.

\section{CONCLUSION}

Health professional migration represents a "brain drain" of highly skilled and qualified individuals. The percentage of foreign physicians in some EU countries has grown up to $30 \%$, and similarly, the percentage of foreign psychiatrists in some has reached up to $40 \%$.

In their recognition of the fact that national skill shortages can cause further imbalance at a global level, the WHO Global Code on International Recruitment of Health Personnel calls on high-in- come countries to strive for self-sufficiency. The goal should be to educate, retain, and sustain enough physicians to staff each country's health care system.

Croatia is one of the three EU countries from which the most physicians emigrate, with both economic and noneconomic factors contributing to emigration decisions and to advantages as well as disadvantages of emigration of Croatian physicians.

Migrant physicians benefit from emigration through high satisfaction with life standard, greater income, professional development, and better working conditions, but there are also clear psychological costs for the emigrants as well as their partners and children: moving away from family members, friends, and a familiar environment; mastering another language and adjusting to life in another country; finding jobs for partners; adjusting to the educational system while perceiving discrimination by colleagues, patients, and general the public (which makes building of a social network and integration into the society difficult). Immigration countries face challenges with foreign-qualified physicians due to their naturally different lingual and cultural backgrounds.

Language proficiency training and national familiarization programs can improve integration of emigrant physicians and their families.

\section{Acknowledgments}

Thanks to Lucija Gruber Zlatec, a student of the IBDP in Birkerød Gymnasium, Denmark, for help with translation of the text.

Conflict of interest: None to declare

\section{REFERENCES}

1. Aluttis C, Bishaw T, Frank MW. The workforce for health in a globalized context: global shortages and international migration. Glob health action (Internet). 2014;7: 10.3402/gha.v7.23611. (cited 2019 dec 23). Available from: doi: 10.3402/gha.v7.23611.

2. World Health Organisation (Internet). Geneva: Global strategy on human resources for health: workforce 2030. (cited 2019 dec 24). Available from: https://www. who.int/hrh/resources/global_strategy_workforce2030_14_print.pdf?ua=1.

3. Croatian Board for Statistics (Drzavni zavod za statistiku) (Internet). Hrvatska: Croatian citizens emigrated abroad, by country of next residence, 2018. (cited 2020 jan 5). Available from: https://www.dzs.hr/. 
4. Drazenovic I, Marina K, Pripuzic D. Dynamics and determinants of emigration: the case of Croatia and the experience of new EU member states. Pub Sect Econ 2018; 42:415-447. Available from: https://doi.org/10.3326/ pse.42.4.3.

5. Vukovic V. The political economy of local government in Croatia: winning coalitions, corruption, and taxes. Pub Sect Econ 2017;41:387-421. Available from: https://doi. org/10.3326/pse.41.4.1.

6. Skeldon R. Of skilled migration, brain drains and policy responses. Int Migr Rev 2009;47:24-8.

7. Cometto G, Tulenko K, Muula AS, Krech R. Health workforce brain drain: from denouncing the challenge to solving the problem. PLos MEd 2013;10:e 1001514.

8. World Health Organisation (Internet). Geneva: The WHO global code of practice on the international recruitment of health personnel. (cited $2019 \mathrm{dec} 28$ ). Available from: https://www.who.int/hrh/migration/code/code_en. pdf?ua=1.

9. Department of public expenditure and Reform (Internet). Campbell (T): Medical workforce analysis. Ireland and European Union compared. Staff paper proposal by Labor Market and Enterprise Policy Division of the Department of Public Expenditure and Reform. c2015 (cited $2019 \mathrm{dec}$ 28). Available from: http://igees.gov.ie/ wp_content/uploads/2014/11/Medical-WorkforceAnalysis.pdf.

10. Aly Z, Tj F. Why pakistani medical graduates must remain free to emigrate. PLos Med 2008;5:0006-8.

11. Humpries N, Crowe S, McDermott C, McAleese S, Brugha R. The consequences of Irland's culture of medical migration. Hum Res of Healt 2017;15:87-90.

12. Prescott $M$, Richter $M$. Transnational nurse migration: future directions for medical anthropological research. Soc Sci Med 2014;107:113-23.

13. Mullan F. The metrics of the physician brain drain. N Eng J Med 2005;353:1810-8.

14. Health Service executive (Internet). Dublin: Towards Successful Consultant Recruitment, Appointment and Retention. Recommendations of a Committee appointed by the the HSE regarding reform of the process for creation, approval, recruitment and appointment ono Consultant posts, inc. c2016 (cited 2019 dec 29). Available from: http://www.hse.ie/eng/staff/Resources/HR-publictions/consultantrecruitment_dec16.pdf.

15. Conell S. The two cultures of health workers migration: a Pacific perspective. Soc Sci Med 2014; 116:73-81.

16. Carr SC, Inkson K, Thorn K. From Global careers to talent flow: Reinterpreting "brain drain". J of World Bus 2005;40:386-98.

17. Mullan F. Physicians and soccer players- African Professional on the Move. N Eng J Med 2007; 353:1810-18.

18. Creighton MJ. The role of aspirations in domestic and international migration. Soc Sci J 2013;50:79-88.

19. Covell CL, Neiterman E, Bourgeault IL. Scoping review about the professional integration of international educated health professionals. Hum Resour Helath 2016;14:38.

20. Bhugra D, Antonio V, Kamaldeep SB. Practical cultural psychiatry. 1 th Edition. Oxford: Oxford University press 2018;23-34.

21. Eisenbruch M. From post-traumatic stress disorder to cultural bereavement: diagnosis of Southeast Asian refugees.Soc Sci Med 1991;33:673-80.
22. Oberg K. Cultural Shock: Adjustment to New Cultural Environments. Practical Anthropology 1960;7:177-82. Available from: https://doi.org/10.1177/009182966000700405.

23. Bhugra D. Migration and mental health. Act Psych Scand (Internet). 2004;20. (cited 2020 jan 1). Available from: https://doi.org/10.1046/j.0001-690X.2003.00246.x

24. Redfield R, Linton R, Herskovits M. Memorandum for the study of acculturation. Amer Anthro Ass 1936;1:149152. Available from: https://doi.org/10.1525/aa.1936. 38.1.02a00330.

25. Knapp B, Bähr H, Dietz M, Dony E, Fausel G, Müller M et al. Beratung und Vermittlung von Flüchtlingen: IAB-Forschungsbericht. Nürnberg: Institut für Arbeitsmarkt- und Berufsforschung (IAB), 2017 (cited 2020 jan 2). Available from: http://doku.iab.de/forschungsbericht/2017/ fb0517.pdf.

26. Klingler C, Marckmann G. Difficulties experienced by migrant physicians working in German hospitals: a qualitative interview study. Human Res for Health 2016;14: 57-60.

27. Ong YL, Bannon M, Paice E. Getting refugee doctors back to work: challenges, obstacles and solutions In: Jackson N, Carter Y (eds). Refugee Doctors: Support, Development and Integration in the NHS: Radcliffe Publishing, London, England 2004;31-7.

28. Khan-Gökkaya S, Higgen S, Mösko M. Qualification programmes for immigrant health professionals: A systematic review. PLoS ONE (Internet). 2019; 14(11): e0224933. https://doi.org/10.1371/journal.pone.0224933. (cited 2019 dec 23). Available from: https://doi.org/10.1371/ journal.pone.0224933.

29. Lai DW, Janki S, Ernest K. Unspoken skills and tactics: Essentials for immigrant professionals in integration to workplace culture. J of Int Migr and Integr 2017;18:93759.

30. Jirovsky E, Hoffmann K, Maier M, Kutalek R. "Why should I have come here?": A qualitative investigation of migration reasons and experiences of health workers from sub-Saharan Africa in Austria. BMC Health Serv Res 2015;15:74-7.

31. Mozetic K. Being highly skilled and a refugee: Self-perceptions of non-european physicians in Sweden. Ref Surv Quart 2018;37:231-51.

32. Bloch A. Refugees in the UK labour market: The conflict between economic integration and policy-led labour market restriction. J of Soci Pol 2008;37:21-36.

33. Slowther A. Non UK qualified physicians and good medical practice: The experience of working within a different professional framework. Report for the General Medical Council. Warwick: University of WarwickWarwick Medical School, 2009.

34. Tjadens, F. Roerink H. Arbeidsmigratie van Verpleegkundigen Naar Nederland. Een Inventarisatie van Ervaringen, Feiten en meningen. [Labour Migration of Nurses to the Netherlands: Inventory of Experiences, Facts and Opinions]. Utrecht: Nederlands Instituut Voor Zorg En Welzijn (NIZW, Netherlands Institute for Care and Welfare), 2002

35. Schultz C, Rijks B. Mobility of Health Professionals to, from and within the European Union. Geneva: International Organization for Migration, 2014;19-20. Available from: https://publications.iom.int/system/files/pdf/ mrs48 web 27march2014.pdf. 
36. Harnois CE, Bastos JL. Discrimination, Harassment, and Gendered Health Inequalities: Do Perceptions of Workplace Mistreatment Contribute to the Gender Gap in Self-reported Health? J Health Soc Behav 2018;59:28399. Available from: doi: 10.1177/0022146518767407.

37. Župarić-Ilijć D. Iseljavanje iz Republike Hrvatske nakon ulaska u Europsku uniju. Zagreb: Friedrich Ebert Stiftung, 2016. Available at: https://www.fes-croatia.org/fileadmin/user_upload/FES_Iseljavanje_web.pdf.

38. Pilar's barometer of Croatian society (2014, 2015 or 2016) (Internet). Zagreb: Institute of Social Sciences Ivo Pilar. Available from: http://barometar.pilar.hr.

39. Juric T. Iseljavanje Hrvata u Njemačku. Gubimo li Hrvatsku. 1. izdanje. Zagreb: Školska knjiga, 2018;35-40.

40. Galic Z (Internet): Iseljavanje visokoobrazovanih: prihodi, ali i korupcija, opći osjećaj netrpeljivosti u društvu, Aktualne ideje.hr, 14. studeni 2019 (cited 2019 dec 23). Available from :http://ideje.hr/iseljavanje-visokoobrazovanih-prihodi-ali-i-korupcija-i-opci-osjecaj-netrpeljivostiu-drustvu/

41. Kolčić I, Čikeš $\mathrm{M}$, Polašek $\mathrm{O}$. Emigration-related attitudes of the final year medical students in Croatia: a cross-sectional study at the dawn of the EU accession. Croat Med J 2014 Oct; 55(5): 452-8.

42. Hrvatska liječnička komora (Internet). Hrvatska: Hrvatsku je napustilo 525 liječnika, krajnje je vrijeme za ozbiljnu reakciju hrvatske Vlade! 14. 12. 2016 (cited 2019 dec 18). Available from: https://www.hlk.hr/hrvatsku-je-napustilo-525-lijecnika-krajnje-je-vrijeme-za-ozbiljnu-reakciju-hrvatske-vlade.aspx

43. Hrvatska liječnička komora (Internet). Hrvatska: Priopćenje za javnost 1. kolovoza 2019 (cited 2020 jan 2). Available from: 2019, https://www.hlk.hr/EasyEdit/UserFiles/ priop\%C4\%87enja/priopcenje-hlk-trazi-zurno-rjesenjepitanja-odredjivanja-placa-lijecnika.pdf.

44. Medicarrera (Internet). Spain: Psychiatrists Denmark, inc. c2019 (cited 2020 january 6). Available from: https://medicarrera.com/healthcare-jobs-scandinavia/ psychiatrists-denmark/.

45. Gruber EN, Sarajlic Vukovic I, Musovic M, Moravek D, Starcevic B, Martic Biocina S, Knez R. Personal wellbeing, work ability, and satisfaction with life and work of psychiatrists who emigrated from Croatia, after Croatia entered EU, compared to their colleagues. In: Proceedings of the 28th European Congress of Psychiatry, Spain, 2020; Electronic supplement of European Psychiatry: Cambridge University Press, 2020; Forthcoming.

46. Lasic I (Internet). Bolnice u komi. Portalnovosti 9. rujna 2019 (cited 2019 dec 28). Available from: https://www. portalnovosti.com/bolnice-u-komi.
47. Troskot Z, Prskalo ME. Key aspects of emigration of qualified workforce: the case of Croatia in comparison to other new member states of the EU. Zagreb: University of Zagreb, Faculty of Law, Economic Sciences, 2018. Masters thesis. Available from: https://urn.nsk.hr/ urn:nbn:hr:199:392550390/rel10020097.

48. Denmark statistik analysis (Internet) (cited $2019 \mathrm{dec} 28$ ). Available from: https://www.dst.dk/Site/Dst/Udgivelser/nyt/GetAnalyse. aspx?cid=33369.

49. Dahl AS. Nästan sex av tio nylegitimerade läkare 2014 utbildade i utlandet. Läkartidningen. Stockholm:DUFD 2015;112-4.

50. Plus- VGR Akademin (Internet). PLUS - lärande och utveckling i svensk hälso- och sjukvård. c2019 (cited 2019 dec 27). Available from: https://www.vgregion.se/ ov/vgr-akademin/utbildningsenheter/plus/?vgrform=1.

51. Tidsskriftet Den Norske Lægeforening (Internet). Skjeggestad $€$, Mjeldheim (GS), Gulbrandsen (P): International medical graduates' perceptions of entering the profession in Norway. c2015 (cited 2020 jan 1). Available from: https://tidsskriftet.no/en/2015/06/internationalmedical-graduates-perceptions-entering-professionnorway.

52. In het hele land: 663 psychiaters (m/v).NOS (Internet). Vleugels (A), de Vries (B): Gezocht. c2017;10. (cited 2019 dec 10). Available from: https://nos.nl/artikel/ 2209831-gezocht-in-het-hele-land-663-psychiaters-mv. html.

53. EDJNet (European data journalism 2019) (Internet). Europe has a shortage of doctors. c2019 (cited 2019 dec 25). Available from: downhttps://www.europeandatajournalism.eu/eng/News/Data-news/Europe-has-a-shortage-of-doctors.

54. Rimmer A. Tackling bullying and undermining in the NHS. BMJ 2019;365:1667-9.

55. German Medical Association (Internet). Medical statistics of the German Medical Association for the year 2015. c2015 (cited 2019 dec 24). Available from: https://www. bundesaerztekammer.de/ueber-uns/aerztestatistik/aerztestatistik-der-vorjahre/aerztestatistik-2015/.

56. Klingler C, Marckmann G. Difficulties experienced by migrant physicians working in German hospitals: a qualitative interview study. Human Resources for Health. 2016;14(1):57. Available from: 10.1186/s12960-0160153-4.

57. Moosa S, Wojczewski S, Hoffmann K, Poppe A, Nkomazana $\mathrm{O}$, Peersman $\mathrm{W}$ et al. The inverse primary care law in sub-Saharan Africa: a qualitative study of the views of migrant health workers. Br J Gen Pract 2014; 64:321-8. Available from: doi: 10.3399/bjgp14X680089. 